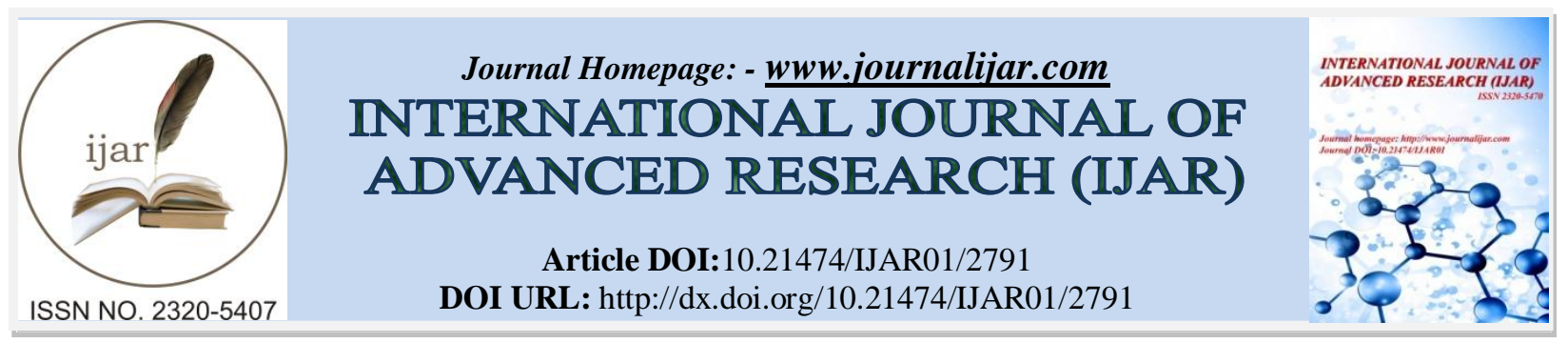

RESEARCH ARTICLE

\title{
RARE CAUSE AND PRESENTATION OF SEVERE HYPERTRIGLYCERIDEMIA.
}

\author{
Adnan Al Awami, Sukayna Al-Faraj and Amal Al Sulaibikh.
}

Department of Emergency Medicine, King Fahad Hospital of the University, Imam Abdulrahman Alfaisal university, Alkhobar, Saudi Arabia

\section{Manuscript Info \\ Abstract \\ Manuscript History}

Received: 15 November 2016

Final Accepted: 17 December 2016

Published: January 2017

Key words:-

hypertriglyceridemia, milky blood.

Copy Right, IJAR, 2016,. All rights reserved.

\section{Introduction:-}

Hypertriglyceridemia (HTG) is defined as an increase in fasting serum triglyceride (TG) levels greater than 150 $\mathrm{mg} / \mathrm{dl}^{1}$. Causes of HTG vary from hereditary to acquired causes, such as diet or medications. Presentation of patients with HTG ranges from being asymptomatic and being diagnosed incidentally, to having minor presentations, such as skin manifestations, and to life-threatening conditions, such as pancreatitis. High TG levels result in turbidity and cloudiness of the blood, and this subsequently interferes with laboratory results ${ }^{2}$.

We present a case of a 42-year-old woman who presented to the emergency department (ED) in an acute confusional state. She had milky white blood secondary to HTG. To the best of our knowledge, this is the first case with a similar clinical picture and initial presentation secondary to a pituitary macroadenoma to be described.

\section{Case Presentation:-}

A 42-year-old woman, not known to have any medical illnesses prior to presentation, was brought to the ED with an altered level of conscious, which was noticed by her family. The patient's symptoms were confusion, abdominal pain, nausea, and vomiting. The patient was noticed to have had six to seven meals per day, and she also consumed large amount of powdered milk of approximately 5 to $6 \mathrm{~L}$ per day.

A physical examination showed that she had an average body mass index and was confused with a Glasgow Coma Scale score of $14 / 15$. Vitals signs showed a temperature of $36.7^{\circ} \mathrm{C}$, heart rate of $114 \mathrm{bpm}$, blood pressure of $135 / 87$ $\mathrm{mmHg}$, respiratory rate of 30 , and $\mathrm{O}_{2}$ saturation of $99 \%$. The rest of the physical examination was unremarkable. A blood sample was collected from the patient to undergo laboratory testing. The blood was milky white (Figure 1).Findings from the initial laboratory investigations that were performed at the ED are shown in Tables 1 and 2.

The patient was then admitted to the intensive care unit and started on anti-lipemic medication, insulin, and heparin. She underwent plasmapheresis three times over 3 consecutive days (Figures 3). She then improved clinically and biochemically (Tables 1 and 2).

Corresponding Author:-Adnan AlAwami.

Address:-Department of Emergency Medicine, King Fahad Hospital of the University, Imam

Abdulrahman Alfaisal university, Alkhobar, Saudi Arabia. 
During the patient's stay at the intensive care unit, she underwent magnetic resonance imaging (MRI) of the head because of the impaired level of consciousness. MRI showed a pituitary macroadenoma (Figures 3 and 4), which could explain the polyphagia experienced by the patient. Then patient was referred for surgical follow up and evaluation after discharge.

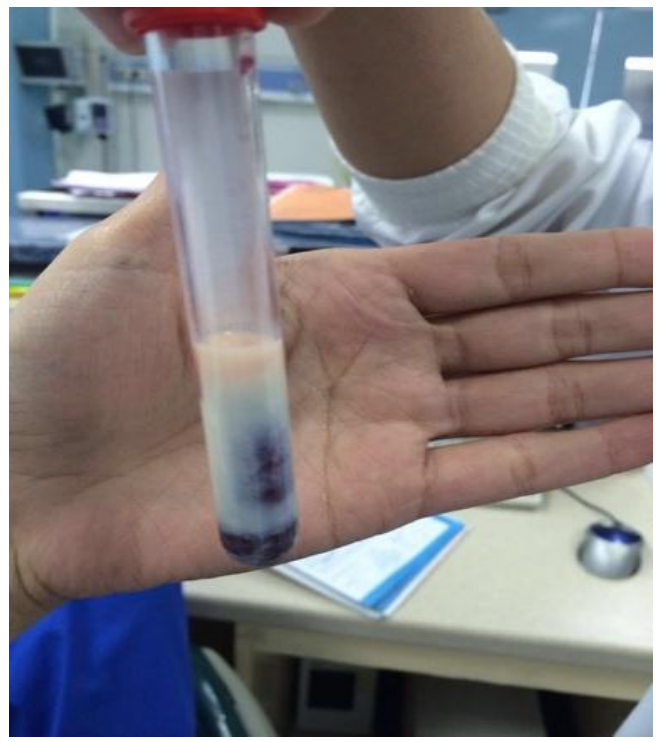

Figure 1:- Milky-colored blood sample upon presentation. Image 2: Same sample shown at (image 1) few seconds after blood extraction

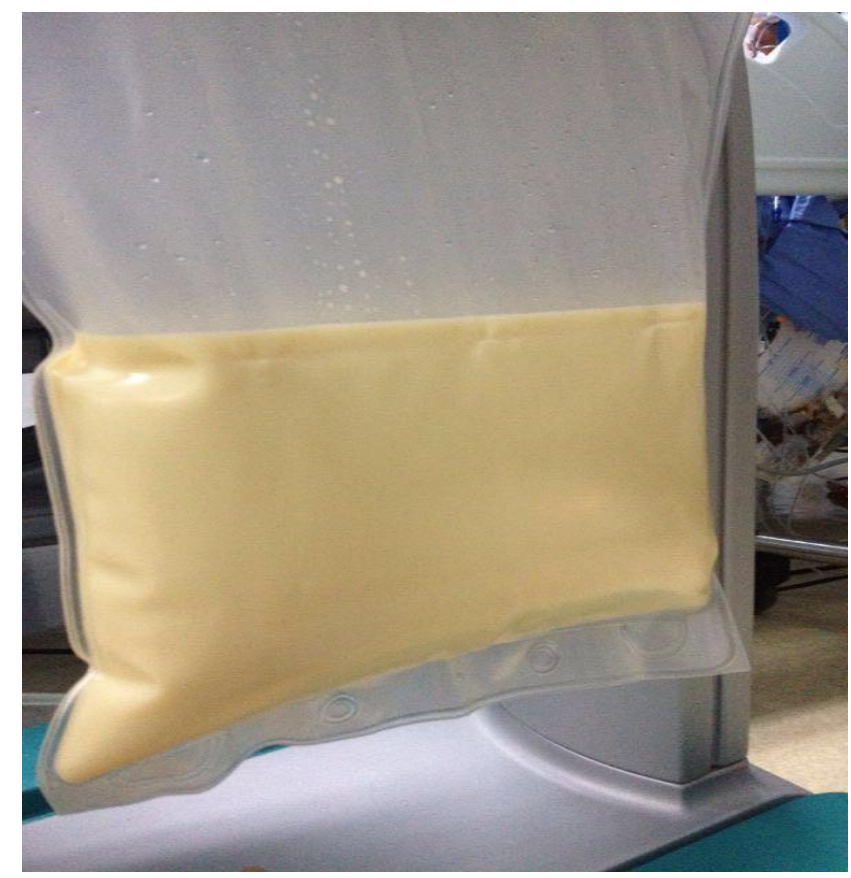

Figure 2:- Milky white blood during plasmapheresis 


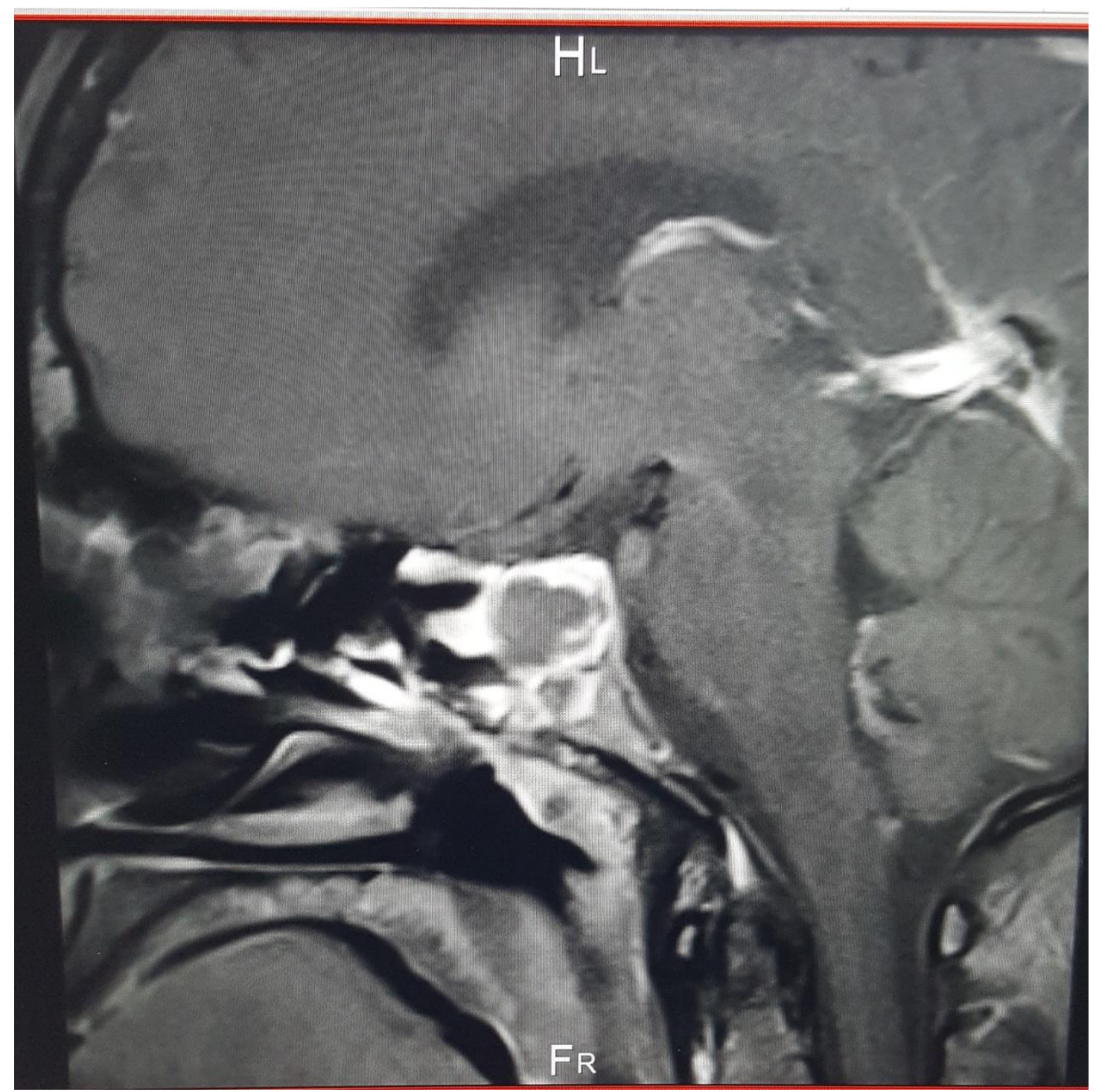

Figure 3:- Sagittal view of MRI showing a $3 \times 2.3-\mathrm{mm}$ pituitary macroadenoma with no enhancement. 


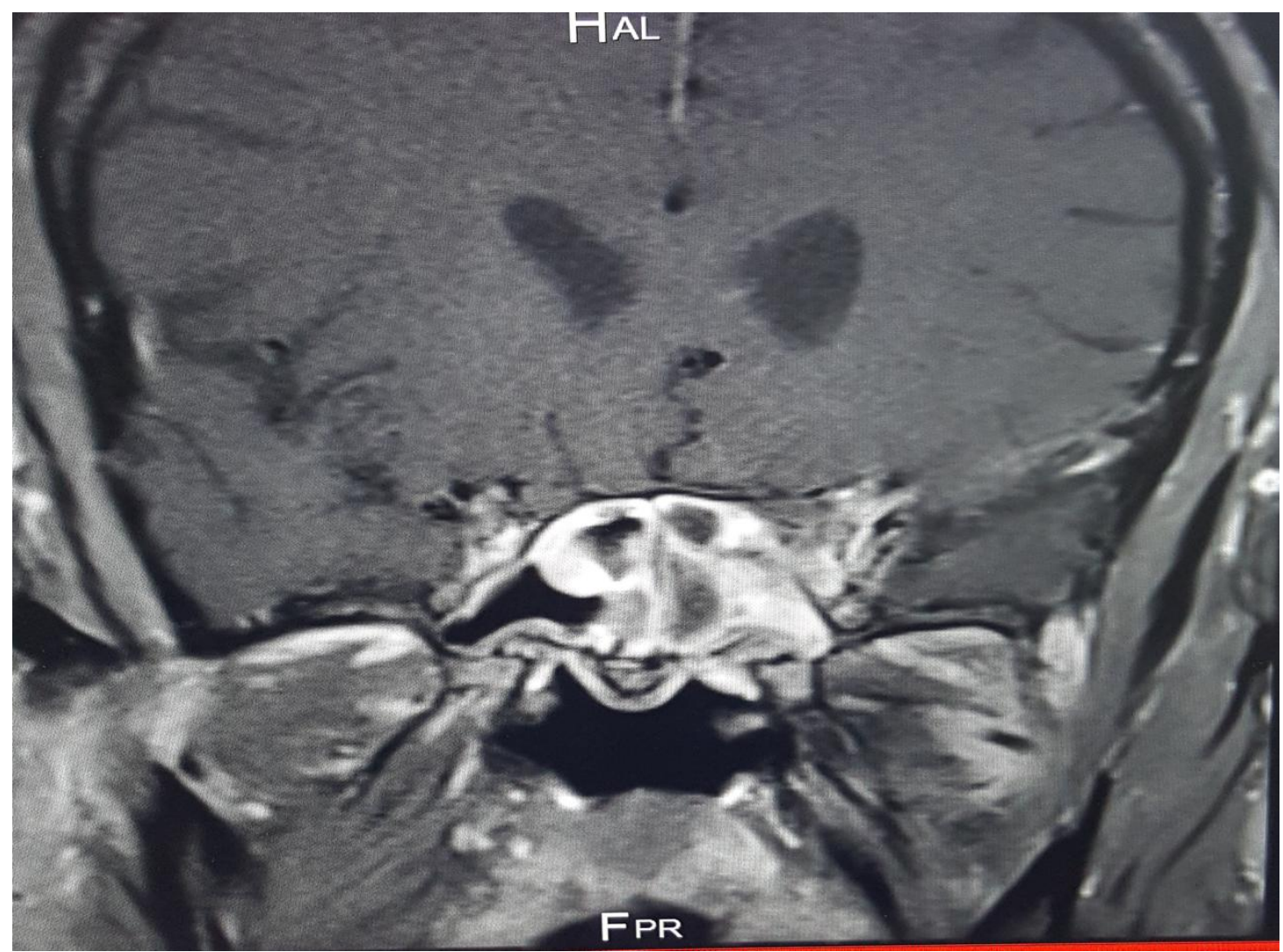

Figure 4:- Coronal view of MRI showing the pituitary adenoma.

Table 1:-Laboratory blood tests results before and after treatment.

\begin{tabular}{|c|c|c|c|c|c|c|c|c|c|c|c|c|c|}
\hline & \multicolumn{3}{|c|}{ CBC } & \multicolumn{4}{|c|}{ Lipid profile } & \multicolumn{6}{|c|}{ LFT } \\
\hline & WBC & $\mathrm{Hb}$ & Plt & TG & Chol & LDL & HDL & $\begin{array}{l}\text { T. } \\
\text { Bil }\end{array}$ & $\begin{array}{l}\text { D. } \\
\text { Bil }\end{array}$ & $\begin{array}{l}\text { AS } \\
\text { T }\end{array}$ & $\begin{array}{l}\text { GP } \\
\mathrm{T}\end{array}$ & $\begin{array}{l}\mathrm{AL} \\
\mathrm{P}\end{array}$ & $\begin{array}{l}\text { GGT } \\
\mathrm{P}\end{array}$ \\
\hline $\begin{array}{l}\text { Before } \\
\text { plasmaphe } \\
\text { resis }\end{array}$ & $\begin{array}{l}3.8 \\
\mathrm{k} / \mathrm{ul}\end{array}$ & $\begin{array}{l}8.9 \\
\mathrm{~g} / \mathrm{dl}\end{array}$ & $\begin{array}{l}230 \\
\mathrm{k} / \mathrm{ul}\end{array}$ & $\begin{array}{l}3760 \\
\mathrm{mg} / \mathrm{d} \\
1\end{array}$ & $\begin{array}{l}907 \\
\mathrm{mg} / \mathrm{d} \\
1\end{array}$ & & able to & proc & ssed b & ause & lipid & $\operatorname{mics}$ & \\
\hline $\begin{array}{l}\text { After } \\
\text { plasmaphe } \\
\text { resis }\end{array}$ & $\begin{array}{l}5.2 \\
\mathrm{k} / \mathrm{ul}\end{array}$ & $\begin{array}{l}7.8 / \mathrm{g} \\
/ \mathrm{dl}\end{array}$ & $\begin{array}{l}174 \\
\mathrm{k} / \mathrm{ul}\end{array}$ & $\begin{array}{l}393 \\
\mathrm{mg} / \mathrm{d} \\
\mathrm{l}\end{array}$ & $\begin{array}{l}160 \\
\mathrm{mg} / \mathrm{d} \\
\mathrm{l}\end{array}$ & $\begin{array}{l}44 \\
\mathrm{mg} / \mathrm{d} \\
1\end{array}$ & $\begin{array}{l}14 \\
\mathrm{mg} / \mathrm{d}\end{array}$ & $\begin{array}{l}0.8 \\
\mathrm{mg} / \mathrm{d} \\
\mathrm{l}\end{array}$ & $\begin{array}{l}0.1 \\
\mathrm{mg} / \mathrm{d} \\
\mathrm{l}\end{array}$ & $\begin{array}{l}8 \\
\mathrm{U} / \mathrm{L}\end{array}$ & $\begin{array}{l}39 \\
\mathrm{U} / \mathrm{L}\end{array}$ & $\begin{array}{l}58 \\
\text { U/L }\end{array}$ & $\begin{array}{l}21 \\
\mathrm{U} / \mathrm{L}\end{array}$ \\
\hline
\end{tabular}

Table 1 CBC, complete blood count; WBC, white blood cell;Hb, hemoglobin; Plt, platelets; TG, triglycerides; Chol, cholesterol; LDL, low-density lipoprotein; HDL, high-density lipoprotein; LFT, Liver function test; T.Bil, Total bilirubin; D.Bil,Direct Bilirubin; AST, aspartate aminotransferase; ALT, alanine aminotransferase; ALP, alkaline phosphatase; GGTP, gamma-glutamyltranspeptidase.

Table 2:- Laboratory blood tests results before and after treatment.

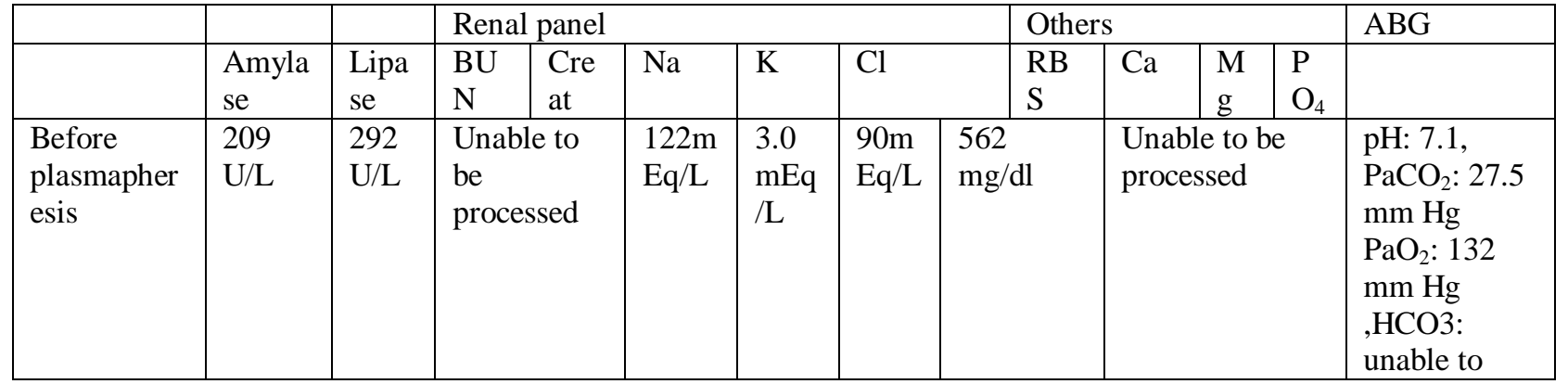




\begin{tabular}{|c|c|c|c|c|c|c|c|c|c|c|c|c|}
\hline & & & & & & & & & & & & processed \\
\hline $\begin{array}{l}\text { After } \\
\text { plasmapher } \\
\text { esis }\end{array}$ & $\begin{array}{l}156 \\
\mathrm{U} / \mathrm{L}\end{array}$ & $\begin{array}{l}57 \\
\mathrm{U} / \mathrm{L}\end{array}$ & $\begin{array}{l}5 \\
\mathrm{mg} / \\
\mathrm{dl}\end{array}$ & $\begin{array}{l}0.4 \\
\mathrm{mg} / \\
\mathrm{dl}\end{array}$ & $\begin{array}{l}144 \mathrm{~m} \\
\mathrm{Eq} / \mathrm{L}\end{array}$ & $\begin{array}{l}3.6 \\
\mathrm{mEq} \\
/ \mathrm{L}\end{array}$ & $\begin{array}{l}114 \\
\mathrm{mEq} / \mathrm{L}\end{array}$ & $\begin{array}{l}197 \\
\mathrm{mg} / \mathrm{dl}\end{array}$ & $\begin{array}{l}7.3 \\
\mathrm{mg} / \\
\mathrm{dl}\end{array}$ & $\begin{array}{l}1.8 \\
\mathrm{mEq} / \\
\mathrm{L}\end{array}$ & $\begin{array}{l}0 \\
8\end{array}$ & $\begin{array}{l}\mathrm{pH}: 7.49, \\
\mathrm{PaCO}_{2}: 39.6 \\
\mathrm{~mm} \mathrm{Hg} \\
\mathrm{PaO}_{2}: 124 \\
\mathrm{~mm} \mathrm{Hg} \\
\mathrm{HCO} 3: 30.7 \\
\mathrm{mEq} / \mathrm{L}\end{array}$ \\
\hline
\end{tabular}

BUN, blood urea nitrogen; Creat, creatinine; Na, sodium; K, potassium; Cl, chloride; RBS, random blood sugar; Ca; calcium; $\mathrm{Mg}$, magnesium; $\mathrm{PO}_{4}$, phosphate; $\mathrm{ABG}$, Arterial blood gas; $\mathrm{PaCo}_{2}$, partial pressure of $\mathrm{CO}_{2} ; \mathrm{PaO}_{2}$, partial pressure of $\mathrm{O}_{2} ; \mathrm{HCO}_{3}$, bicarbonate.

\section{Case Discussion:-}

We report a case of severeHTG that was induced by excessive milk powder ingestion (polyphagia), which could be explained by the presence of a pituitary macroadenoma. To the best of our knowledge, this is the first reported case of severe HTG that was secondary to such a cause.

There have been few previously reported cases similar to our case, in which the patient presented with milky white blood. Most of the previously reported cases were from India, Nepal, and the USA. Sandhya reported a patient aged 43 years old, with type 2 diabetes mellitus on irregular treatment, who presented with abdominal pain. The patient had a random blood sugar level of $640 \mathrm{mg} / \mathrm{dl}$. The patient's TG level was 17,300 mg/dl. The patient was treated accordingly as a case of diabetic ketoacidosis and severe $\mathrm{HTG}^{3}$.Another patient with milky white blood was reported from Nepal in 2010. A 66-year-old man, who had hypertension, and was an alcoholic and a smoker, complained of joint pain. The patient had a history of eating a large amount of fried pork and drinking a large amount of alcohol. The patient's TG level was $1621 \mathrm{mg} / \mathrm{dL}^{4}$. An asymptomatic case was reported in the USA, in which the patient had no complaints and was incidentally found to have white opaque blood upon a regular checkup 5 .

HTG is defined as an increase in fasting serum TG levels greater than $150 \mathrm{mg} / \mathrm{dl}$. Recent Endocrine Society guidelines classified HTG into the following four categories: mild $(150-199 \mathrm{mg} / \mathrm{dL} ; 1.7-2.2 \mathrm{mmol} / \mathrm{L})$, moderate $(200-999 \mathrm{mg} / \mathrm{dL} ; 2.3-11.2 \mathrm{mmol} / \mathrm{L})$, severe $(1000-1999 \mathrm{mg} / \mathrm{dL} ; 11.2-22.4 \mathrm{mmol} / \mathrm{L})$, and very severe $(>2000$ $\mathrm{mg} / \mathrm{dL} ;>22.4 \mathrm{mmol} / \mathrm{L}$ ). ${ }^{1}$ in our case, the patient was categorized as having severe HTG. Her HTG level at the ER was $3760 \mathrm{mg} / \mathrm{dl}$. The underlying pathogenesis of HTG is due to increased production and/or intake, reduced catabolism, or a combination of both. HTG can be either primary or secondary. Primary HTG is mainly due to genetically-based familial hyperlipidemias. ${ }^{6}$ Familial combined hyperlipidemia is the most common heritable dyslipidemia with a prevalence of $1-2 \%$ in the general population. It is an autosomal condition, associated with insulin resistance, obesity, and premature cardiovascular disease. ${ }^{6,7}$ There are other less common heritable dyslipidemias, such as familial HTG, chylomicronemia syndrome, and type III hyperlipidemia or dysbetalipoprotieinemia. ${ }^{7}$ Secondary causes of HTG includea high carbohydrate and fat diet, drugs, such as bile acid sequestrants, ${ }^{8}$ retinoids, ${ }^{9}$ and antihypertensive drugs (thiazide, furosemide, and beta-blocker agents), especially in patients with underlying genetic hyperlipidemia. ${ }^{10}$ Conditions with insulin resistance, such as diabetes mellitus type 2, metabolic syndrome, polycystic ovarian syndrome, acromegaly, and pregnancy, increase the production of $\mathrm{TG}$, leading to $\mathrm{HTG}^{10,11}$. Acute hepatitis and nephrotic syndrome can also cause HTG. ${ }^{12,13}$

In our case, the patient did not have any previous medical illnesses, obesity, or the use of any drugs. She was consuming a high amount of carbohydrate and fat, which is thought to be secondary to the pituitary adenoma that was later diagnosed. Patients with HTG are usually asymptomatic, but they may present with some characteristic features, including eruptive xanthomas and fatty changes in the liver. The most feared clinical feature of HTG is the risk of developing life-threatening acute pancreatitis. Studies have shown that TG levels $>500 \mathrm{mg} / \mathrm{dL}$ increase the risk of developing acute pancreatitis. ${ }^{14}$ High serum TG levels can interfere with laboratory results Chylomicrons and very-low-density lipoprotein are suspended particles that scatter light, which results in cloudiness or turbidity of the blood. ${ }^{2}$ This may result in the delay or underestimation of electrolyte concentrations in the blood. This situation can 
be minimized by ultra-centrifuging the sample by reducing the lipid or by using polymers to precipitate the lipids in the sample. ${ }^{15}$

Management of HTG should consist of non-pharmacological and pharmacological treatment, which is known as conventional management. Non-pharmacological therapy basically targets the life style of the patient. This therapy includes modification of the diet by restriction of carbohydrates and a fat-rich diet, or introducing a diet rich in omega-3 fatty acids, ${ }^{16}$, exercise, and weight loss. Physicians recommend that in severe HTG (>1000 mg/dL), dietary fat intake should be less than $10 \%$ of total caloric intake. If TG levels are 400-1000 mg/dL, then dietary fat should be $20 \%$ of total of caloric intake ${ }^{17}$.

Pharmacological therapy should be considered according to clinical practice guidelines when TG levels are greater than $200 \mathrm{mg} / \mathrm{dl} .{ }^{17,18}$ This therapy includes anti-lipidemic agents, insulin, and heparin. Anti-lipidemic agents include fibrates, statins, and niacin. Fibrates, such as gemfibrozil, are the first-line agent for controlling TG levels. ${ }^{18}$ Fibrates can reduce up to $30-50 \%$ of TG in the serum by several mechanisms, including increased catabolism of TG by increasing oxidation and by decreasing production of very-low-density lipoprotein by the liver. ${ }^{19,20}$ Statins are HMG-CoA reductase inhibitors (rate-limiting enzyme of cholesterol synthesis). Statins mainly lower cholesterol levels, and can lower TG levels by $25-30 \%$ with high doses. ${ }^{21}$ Therefore,statinscannot be used alone. Statins can be used with fibrates, but with caution, by close monitoring of creatinine kinase because they may increase the chance of rhabdomyolysis. ${ }^{21,22}$ Niacin can be used as well, but its effects in lowering TG levels are only 10-30\%. Insulin and low-dose heparin can be used to lower TG levels, but both increase lipoprotein lipase, which degrades TG to glycerol and free fatty acids. ${ }^{23}$

Plasmapheresis is a therapeutic procedure where the plasma is separated from the blood and filtered, and then returned. Plasmapheresis should be indicated in case of failure of conventional treatment to lower TG levels. A previous study suggested that TG levels greater than $2000 \mathrm{mg} / \mathrm{dl}$ should be an indication for plasmapheresis to avoid systemic complications, such as acute pancreatitis. ${ }^{24,}{ }^{25} \mathrm{~A}$ single session of plasmapheresis can reduce TG levels up to $70 \%$, producing a clear, clinical, and laboratory improvement ${ }^{24,25}$. Plasmapheresis is a relatively safe procedure with few complications, such as urticarial, paresthesia, rigors, headaches, hypotension, and muscle cramps. ${ }^{26}$

\section{Conclusion:-}

To the best of our knowledge, this is the first case of Sever HTG secondary to excessive milk ingestion and polyphagia which was caused by macroadenoma of the pituitary gland. Physician must be aware of such etiology for further management considerations in addition to the usual medical therapy.

\section{References:-}

1. Berglund L, Brunzell JD, Goldberg AC, Goldberg IJ, Sacks F, Murad MH, et al, Endocrine society. Evaluation and treatment of hypertriglyceridemia: an Endocrine Society clinical practice guideline.I

2. Kroll MH, Elin RJ. Interference with clinical laboratory analyses. ClinChem 1994;40:1996-2005.

3. Sandhya, V., Balasubramanian, A., Rajasekar, D., Kothai, G. and Sundari, S.M., Pink Blood. TC, 600, p.168.

4. Paudel, Y.P., Kasyap, A.K., Shrestha, A. and Baral, R., 2010. High lipemic serum: a case report. Nepal Med Coll J, 12(1), pp.61-62

5. Pillai, A.S., 2009. White, opaque fluid in a blood draw. Hypertriglyceridemia. American family physician, 79(8), p.699.

6. Yuan G, Al-Shali KZ, Hegele RA. Hypertriglyceridemia: its etiology, effects, and treatment. CMJA 2007;176:1113-1120.

7. Brunzell JD. Clinical practice. Hypertriglyceridemia. NEJM 2007;357:1009-1017.

8. Crouse 3rd JR. Hypertriglyceridemia: a contraindication to the use of bile acid binding resins. The American Journal of Medicine 1987;83:243-248.

9. Vu-Dac N, Gervois P, Torra IP, et al. Retinoids increase human apo c-iii expression at the transcriptional level via the retinoid $\mathrm{x}$ receptor. Contribution to the hypertriglyceridemic action of retinoids. The Journal of Clinical Investigation 1998;102:625-632.

10. Stone NJ. Secondary causes of hyperlipidemia. The Medical Clinics of North America 1994;78:117-141.

11. Carr MC, Brunzell JD. Abdominal obesity and dyslipidemia in the metabolic syndrome: importance of type 2 diabetes and familial combined hyperlipidemia in coronary artery disease risk. The Journal of Clinical Endocrinology and Metabolism 2004;89:2601-2607. 
12. Luo $\mathrm{L}, \mathrm{Pu} \mathrm{X}$, Wang $\mathrm{Y}$, et al. Impaired plasma lipid profiles in acute hepatitis. Lipids in Health and Disease 2010;9:5.

13. Kronenberg F. Dyslipidemia and nephrotic syndrome: recent advances. Journal of Renal Nutrition: The Official Journal of the Council on Renal Nutrition of the National Kidney Foundation 2005;15:195-203.

14. Lindkvist B, Appelros S, Regnér S, Manjer J. A prospective cohort study on risk of acute pancreatitis related to serum triglycerides, cholesterol and fasting glucose. Pancreatology 2012;12:317.

15. Ryder KW, Glick MR. Erroneous laboratory results from hemolyzed, icteric, and lipemic specimens. ClinChem 1993;39:175-176.

16. Mensink RP, Zock PL, Kester AD, et al. Effects of dietary fatty acids and carbohydrates on the ratio of serum total to hdl cholesterol and on serum lipids and apolipoproteins: a meta-analysis of 60 controlled trials. The American Journal of Clinical Nutrition 2003;77:1146-1155.

17. Capell WH, Eckel RH. Severe hypertriglyceridemia with a historyof treatment failure. Nature ClinPractEndocrinolMetab 2005;1:53-58.

18. Rosen IM, Sams RW 2nd. Common questions in managing hyperlipidemia. Prim Care Clin Office Pract 2006;33:903-921.

19. Abourbih S, Filion KB, Joseph L, et al. Effect of fibrates on lipid profiles and cardiovascular outcomes: a systematic review. The American Journal of Medicine 2009;122:e961-e968.

20. Rubins HB, Robins SJ, Collins D, et al. Gemfibrozil for the secondary prevention of coronary heart disease in men with low levels of high-density lipoprotein cholesterol. Veterans affairs high-density lipoprotein cholesterol intervention trial study group. The New England Journal of Medicine 1999;341:410-418.

21. Pasternak RC, Smith SC, Bairey-Merz CN, et al. ACC/AHA/NHLBI clinical advisory on the use and safety of statin. J Am CollCardiol 2002;40:567-572.

22. Graham DJ, Staffa JA, Shatin D, et al. Incidence of hospitalized rhabdomyolysis in patients treated with lipidlowering drugs. JAMA 2004;292:2585-2590.

23. Berger Z, Quera R, Poniachik J, et al. Heparin and/or insulin treatment of acute pancreatitis caused by hypertriglyceridemia. Rev Med Chil 2001;129:1373-1378.

24. Furuya T, Komatsu M, Takahashi K, et al. Plasma exchange for hypertriglyceridemic acute necrotizing pancreatitis: report of two cases. TherApher 2002;6:454-458.

25. Ewald N, Kloer HU. Severe hypertriglyceridemia: an indication for apheresis? AtherosclerSuppl 2009;10:4952.

26. Bramlage CP, Schröder K, Bramlage P, et al. Predictors of complications in therapeutic plasma exchange. J ClinApher 2009;24:225-231. 